
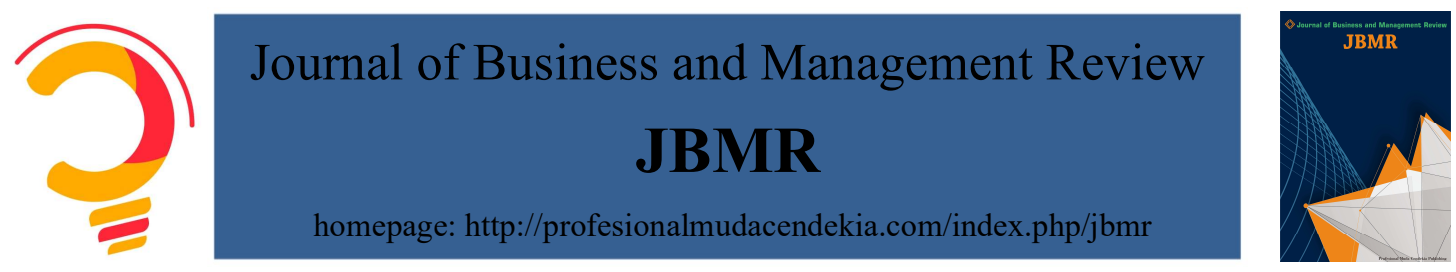

\title{
The Effect of Perceived Usefulness and Perceived Ease of Use on the Technology Acceptance Model to Use Online Travel Agency \\ Adi Wicaksono 1,
}

Anita Maharani 2*

1,2 Master Program, Binus Business School, Bina Nusantara University, Jakarta, Indonesia

ARTICLE INFO ABSTRACT

ISSN: $2723-1097$

\section{Keywords:}

Percieved usefulness; Percieved ease of use; Behavioural Intention; TAM; Online Travel Agency
Perceived Usefulness (PU) and Perceived Ease of Use (PEU) are factors that can affecting Behavioural Intention (BI) in the Technology Acceptance Model (TAM). This study aims to determine the effect of PU and PEU on BI of PT XYZ users. This research is a non-experimental study using quantitative methods and a random sampling technique. Data were collected through a questionnaire and processed using Statistical Product and Service Solution (SPSS) with a version of 22.00. There were 80 participants in the research, divided into 58 participants who were PT XYZ users and 22 other participants who had never used PT XYZ. The results showed that there was a significant effect of PU and PEU on $B I$ with a value of $F=95.483, R^{2}=0.713$, and $p=0.000<0.05$. The contribution of PU and PEU to PEU was $71.3 \%$. Then, partially PU contributed $62.4 \%$ and PEU contributed $68.9 \%$ to BI. Thus, it can be concluded that for PT XYZ users, the effect of PEU is greater than PU.

\section{Introduction}

Every year, technological sophistication develops rapidly. This makes almost every activity or daily activity cannot escape the use of technology. With the development of increasingly advanced technology and the shifting needs of individuals who emphasize convenience and practicality in their activities, the presence of the internet helps to achieve the desired goals (Setiawan, 2017). Now, the application of technology can occur anywhere, such as in the economic, health, employment, tourism, and many other sectors.

In 2019, the number of internet users in Indonesia is projected to be 175 million or $65.3 \%$ of the total 268 million Indonesian population (Investorid, 2019). The projected increase in internet users is expected to have a positive impact, especially in electronic commerce (e-commerce). This has made businesses evolve into the digital realm, namely with online businesses that are continuously being developed today, such as websites that become imperative for companies to develop their online business.

According to Fishbein \& Ajzen (1975), the Technology Acceptance Model (TAM) indicates the use of the system as an important indicator of technology acceptance. In

Journal of Business and Management Review Vol. 1 No. 52020 Page 313- 328

DOI: $10.47153 /$ jbmr 15.502020

*Corresponding Author

Email address: anita.maharani@binus.edu 
which, e-commerce also looks very sensitive to security issues and risks that will impact internet user trust. Therefore, the TAM is expected to affect the Perceived Ease of Use (PEU) of e-commerce for today's internet users. TAM is also expected to get a broader perspective and a better explanation regarding the acceptance of e-commerce in terms of trust for internet users (Iqbaria et al., 1997 in Santika \& Dewi, 2018).

One of the companies in Indonesia that is following the development of technology and the use of e-commerce is PT XYZ. This company focuses on a website, which includes various features such as online booking and ticketing which provides ticket reservation services. The company was founded in 2011 by Wenas, Dimas, Gaery and Natali. PT XYZ is an online company that is engaged in providing ticket services for various types of transportation, hotels, and other entertainment tickets online that can be accessed by various groups of people. In general, reservations for travel tickets, hotels, and entertainment tickets are made during the holidays or business trips.

The Online Travel Agency (OTA) business is currently growing in Indonesia, especially PT XYZ. According to data from Phocuswright and Expedia (which researches the OTA market in Australia, China, Japan, India, Indonesia, Malaysia, New Zealand, Singapore and Thailand), the Asia Pacific travel online booking market in 2011 reached USD 1.6 billion per year, which is predicted to increase by $30-40 \%$ and the value of hotel reservations in Indonesia through OTA reaches USD 200 million or Rp 2 trillion per year, with an average growth rate of $200-300 \%$ annually. These numbers really make Indonesia as a potential market in developing the online travel market.

Based on a survey through the JakPat Mobile Survey Platform in February 2018, respondents to the Indonesian population include: $71.44 \%$ of respondents have used OTA services for ticket or hotel reservation needs in the last six months, between 50 $70 \%$ respondents use PT XYZ and / or ABC ( $\mathrm{ABC}$ is a direct competitor of PT XYZ) to reserve flight tickets, train tickets, and / or hotel rooms, $83.95 \%$ of respondents use smartphones to access OTA services, and $69.26 \%$ make payments for OTA services via bank account transfers / ATM.

PT XYZ application itself can be downloaded via the Apple App Store for iOS, and Google Play Store for Android. With the PT XYZ application, all features can be enjoyed directly via a smartphone. Attractive promos prepared through the mobile application include: discounted prices for transactions on the PT XYZ application; PT $X Y Z$ customer service is ready to provide 24-hour service; a point system that can be exchanged for other attractive products / services or in the form of discounts for subsequent purchases, last minute hotel reservations, and can make rental car bookings. In addition to the completeness of the services offered, PT XYZ also makes it easy for users to compare prices between different airlines according to user preferences. 
Greater consumer trust in PT XYZ service motivates customers to use the service via the internet. This research tries to measure the quality of the PT XYZ website to improve PT XYZ management. Therefore, researchers are motivated to further research and make this study with the title: "The Effect of Perceived Usefulness and Perceived Ease of Use on the Technology Acceptance Model to Use Online Travel Agency: A Case Study of PT XYZ".

\section{Literature Review}

\section{E-commerce}

Electronic commerce (E-commerce) is behaviour to make purchases, sales, transport, trade data, goods or services using the internet or other networks. Sales and purchases in e-commerce can be carried out in a business-to-customer or business-tobusiness manner. There are five components in e-commerce, namely (a) people, (b)

public policy, (c) marketing and advertising, (d) support services, and (e) business partnerships.

First, people include sellers, buyers, intermediaries, information systems and technology specialists, employees, and other participants. Second, public policies are applicable laws and policies, such as privacy and taxes determined by the government and appropriate technical standards (Turban et al., 2018). Third, marketing and advertising is important to do as a condition that supports the company, such as conducting market research, promotion, creating web content, and determining target markets. Fourth, support services to support e-commerce, from creating payment content to shipping, including order fulfilment, logistics, payment, content, and security system development. Finally, business partnerships are joint ventures, exchanges, or business partnerships from various fields that are usually established through the supply chain (Turban et al., 2018). Need to know, PT XYZ 's business partners include airlines, hotels, entertainment industry, and so on.

\section{The Social Customer}

Social customers or digital customers are members involved in social networks who provide their opinions on products, services, vendors, do online shopping, and understand the policies and strengths of their social communities to provide benefits. The participation process of social customers can occur from the influence of the people around them, such as friends, friends of friends, and so on (Turban et al., 2018). In this case, PT XYZ users who have successfully performed transactions can influence their social circle to use PT XYZ services as well. The influence of the ripple effect is what organizations pay great attention to.

\section{Online Travel and Tourism (Hospitality) Services}


Seeing the development of online travel that is very fast and increasingly popular, companies need to pay attention to three important trends that need to be carried out by online travel agents, namely providing superior services to differentiate from competitors, providing services that can simplify travel searches (including the best prices according to user preferences ), and using social media to present content for tourists (Turban et al., 2018).

Online travel agents have advantages that most conventional travel agents do not offer, such as having reviews that travellers can see directly, tracking travel fares and comparing in person, warnings by offering low fares via e-mail, clear directions because connected directly to the map, and the freedom of users to choose and plan trips (Turban et al., 2018).

\section{Technology Acceptance Model}

Davis, J. (1986, 1989) developed the Technology Acceptance Model (TAM) by adopting the Theory of Reasoned Action (TRA) initiated by Fishbein and Ajzen (1975, 1980). TAM is defined as a model used for the purpose of identifying and evaluating any factors that can affect individual behaviour towards the acceptance of technology or information systems. Basically, TAM has a concept to explain the cause and effect of the belief in the benefits and ease of use, behaviour, purpose, and actual use of users (in Weerasinghe \& Hindagolla, 2018). Factors that can affect TAM include Perceived Usefulness and Perceived Ease of Use.

\section{Perceived Usefulness}

According to Davis (in Hussein et al., 2019), Perceived Usefulness (PU) is defined as a person's or organization's belief in a system that can facilitate their work. When someone does not believe the system is able to help him in doing work, then that person or organization has no intention of using it (Aditya \& Wardhana, 2016). According to Susanto and Aljoza (2015) there are several dimensions of PU, namely making work easier, increasing productivity, increasing work effectiveness, increasing job performance and helping to get promotions, bonuses and other incentives.

\section{Perceived Ease to Use}

Perceived Ease of Use (PEU) can be defined as a person's or an organization's belief in a system that can help him be free from a job. There are several dimensions of PEU, such as ease of navigation, fast response, having a good and easy to understand display or interface, and can be accessed anywhere and anytime (Susanto \& Aljoza, 2015). According to Igbaria et al. (1995), PEU is an important factor that influences one's intention to use information technology systems (in Osman et al., 2016).

\section{Behavioural Intention}


According to Godin and Kok (1996), Behavioural Intention (BI) is an individual or organizational intention or effort to achieve a desired goal that has an impact on consumer behaviour (in Jin et al., 2015). According to Ranadie and Sharif (2019), BI can be described as an intention to do something, which will later become a habit.

\section{Perceived Usefulness, Perceived Ease of Use and Behavioral Intention}

Nysveen et al. stated that BI in the use of a mobile technology service is strongly supported by several factors, namely PU and PEU (in Aditya \& Wardhana, 2016). This is in accordance with the statement conveyed by Doll and Torkzadeh, 1998 (in Elkaseh, et al., 2016) which states that PU and PEU are variables that can affect the formation of $\mathrm{BI}$ in system use.

\section{Analysis Model}

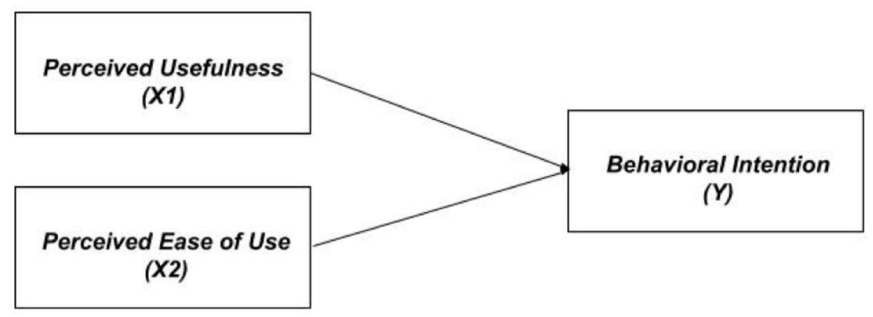

Figure 1. Analytical Framework Model

\section{Research Hypothesis}

Table 1. Research hypothesis

H1 Perceived Usefulness and Perceived Ease of Use have a significant effect on Behavioural Intention on PT $X Y Z$ Users in Indonesia.

H2 Perceived Usefulness has a significant effect on Behavioural Intention on PT XYZ Users in Indonesia.

H3 Perceived Ease of Use has a significant effect on Behavioural Intention in PT XYZ Users in Indonesia.

\section{Method}

\section{Type of Research}

This type of research used in this study is quantitative research. Quantitative research focuses on recording as much data as possible from a broad population, although it is large, it can be easily processed, either through statistical formulas or computers (Bungin, 2013). This study uses a questionnaire as a tool to collect data from respondents. 


\section{Population and Sample}

The population in the research methodology is defined as a group of subjects who will be the research targets to be used as data sources in research (Bungin, 2013). The population in this study are all PT XYZ users in Indonesia. The sample is a portion of the population that is used to represent the population under study (Bungin, 2013). The sample of this study was 80 participants.

This study uses random sampling or random data collection without any limitations on certain characteristics or criteria. In this study, the measurement of validity, reliability, and regression was tested using Software Statistical Product and Service Solutions (SPSS) with a version of 22.00.

\section{Data Collection Methods}

The data used are primary data and secondary data. Primary data is data taken from data sources, while secondary data is data taken from second or secondary sources (Bungin, 2013). This study uses a questionnaire as primary data and other sources as secondary data. Each construct indicator is measured using a Likert scale, namely one to five. The Likert scale is a scale consisting of four or more items that are used to measure satisfaction, opinions, and also individual perceptions of certain objects or phenomena (Maryuliana et al., 2016). Information on the Likert scale used in this study are as follows: 1 = strongly disagree, $2=$ disagree, $3=$ neutral, $4=$ agree, and $5=$ strongly agree.

\section{Operational Definition}

Table 2. Operational Definition of Variables

\begin{tabular}{|c|c|c|}
\hline No & Variable & Indicator \\
\hline 1 & $\begin{array}{l}\text { Perceived } \\
\text { Usefulness } \\
\quad(P U)\end{array}$ & $\begin{array}{l}\text { According to Lockett et al. and Hu et al. in Hu et al. (2019); Renadie and } \\
\text { Sharif (2019), PU indicators include: } \\
\text { - Make transactions easy } \\
\text { - Useful } \\
\text { - Saving time } \\
\text { - Can meet the needs } \\
\text { - Increase efficiency }\end{array}$ \\
\hline 2 & $\begin{array}{l}\text { Perceived Ease } \\
\text { of Use (PEU) }\end{array}$ & $\begin{array}{l}\text { According to Cheng et al. and Wang et al. in Hu et al. (2019); Renadie and } \\
\text { Sharif (2019), PEU indicators include: } \\
\text { - Easy to understand } \\
\text { - Simple and easy to use } \\
\text { - Avoid distraction } \\
\text { - Easy to access }\end{array}$ \\
\hline 3 & $\begin{array}{l}\text { Behavioural } \\
\text { Intention (BI) }\end{array}$ & $\begin{array}{l}\text { According to Renadie and Sharif (2019), BI indicators include: } \\
\text { • Intention to use }\end{array}$ \\
\hline
\end{tabular}




\section{Test Instruments}

This study uses two test tools to test the research instrument, namely the validity test and reliability test.

Validity

Now and Bougie (2013) explain that validity is a test tool to find out how well a measuring instrument measures what is being measured. The validity test uses the Pearson correlation measurement tool between indicators and total indicators. The test results are declared valid if the significant level of Pearson correlation $\leq 0.05$. The results show that all indicators have good validity with a significant value of the Pearson correlation below 0.05 .

Table 3. Validity Test Results

\begin{tabular}{lcccc}
\hline Correlations & & & & \\
\hline & & $Y$ & $X 1$ & $X 2$ \\
Pearson Correlations & $Y$ & 1.000 & .790 & .830 \\
& $X 1$ & .790 & 1.000 & .855 \\
& $X 2$ & .830 & .855 & 1.000 \\
Sig. (I-tailed) & $Y$ & - & .000 & .000 \\
& $X 1$ & .000 & - & .000 \\
$N$ & $X 2$ & .000 & .000 & - \\
& $Y$ & 80 & 80 & 80 \\
& $X 1$ & 80 & 80 & 80 \\
& $X 2$ & 80 & 80 & 80 \\
\hline
\end{tabular}

\section{Reliability}

Now and Bougie (2013) state that reliability in a measurement shows how far the measurement is unbiased / error free and ensures that the measurement results are consistent over time for all the variables in it. To measure reliability using the Cronbach alpha measuring instrument. The statement is said to be reliable if the Cronbach alpha value is greater than 0.70 . The data displayed shows that all items have good reliability with a Cronbach alpha value above 0.70 .

Table 4. Reliability Test Results

\begin{tabular}{|c|c|c|c|c|c|}
\hline \multicolumn{6}{|l|}{$\begin{array}{l}\text { Item-Total } \\
\text { Statistics }\end{array}$} \\
\hline & $\begin{array}{l}\text { Scale Mean if } \\
\text { Item Deleted }\end{array}$ & $\begin{array}{l}\text { Scale Variance if } \\
\text { Item Deleted }\end{array}$ & $\begin{array}{l}\text { Corrected Item- } \\
\text { Total } \\
\text { Correlation }\end{array}$ & $\begin{array}{l}\text { Squared } \\
\text { Multiple } \\
\text { Correlation }\end{array}$ & $\begin{array}{l}\text { Cronbach's } \\
\text { Alpha if Item } \\
\text { Deleted }\end{array}$ \\
\hline
\end{tabular}




\begin{tabular}{llllll}
\hline PU1 & 32.9000 & 36.192 & .846 & .827 & .945 \\
PU2 & 32.8375 & 35.530 & .871 & .830 & .943 \\
PU3 & 32.8375 & 36.112 & .856 & .792 & .944 \\
PEU1 & 32.8500 & 36.382 & .819 & .787 & .946 \\
PEU2 & 32.7375 & 36.019 & .859 & .837 & .944 \\
PEU3 & 32.7375 & 36.424 & .865 & .842 & .944 \\
PEU4 & 33.4375 & 39.237 & .579 & .498 & .957 \\
BI1 & 32.7750 & 37.898 & .770 & .625 & .949 \\
BI2 & 32.7875 & 37.891 & .793 & .689 & .948 \\
\hline
\end{tabular}

Regression Analysis

This study uses multiple linear regression analysis techniques. The independent variables in this study are satisfaction (X1) and motivation (X2), while the dependent variable is employee performance $(\mathrm{Y})$. Linear regression analysis has a formula:

$$
Y=\propto+\beta 1 X 1+\beta 2 X 2+e
$$

Information $=$

Y: Behavioral Intention (BI), $\propto$ : Constants, X1: Perceived Usefulness (PU), X2: Perceived Ease of Use (PEU), $\beta 1$ : Variable Regression Coefficient Perceived Usefulness (PU), $\beta 2$ : Variable Regression Coefficient Perceived Ease of Use (PEU), e: Error Level.

T Test

The $t$ test is used to show how far the influence of one independent variable individually is in explaining the variation of the dependent variable (Ghozali, 2012). The $t$-value test was conducted to partially test the effect of the independent variable on the dependent variable. The determination in the $t$ statistical test according to Ghozali (2012) is as follows:

- If the probability / significance value $\leq 0.05$ then Ha is accepted. Ha is accepted if the independent variable has a positive effect on the dependent variable.

- If the probability / significance value> 0.05 then Ha is rejected. Ha rejected means that the independent variable has no positive effect on the dependent variable.

Partial Correlation Coefficient Test

The correlation coefficient is a statistical measure of the covariance or association between two variables. The correlation coefficient ranges from +1 to -1 . The correlation coefficient shows the strength of the linear relationship and the direction of the relationship between two random variables. If the correlation coefficient is 
positive, then the two variables have a unidirectional relationship (Ghozali, 2012). This means that if the value of variable $X$ is high, then the value of variable $Y$ will be high too. Conversely, if the correlation coefficient is negative, then the two variables have an inverse relationship. This means that if the value of variable $X$ is high, then the value of variable $Y$ will be low, and vice versa. To make it easier to interpret the strength of the relationship between the two variables, the author provides the following criteria (Ghozali, 2012) if 0: There is no correlation between two variables, $>0$ - 0.25: Very weak correlation, > 0.25 - 0.5: Fair correlation, > 0.5 - 0.75: Strong correlation, > 0.75 - 0.99: Very strong correlation, 1: Perfect correlation.

Test of the Coefficient of Determination (F)

Ghozali (2012) states that the F statistical test is used to show whether all the independent variables included in the model have multiple effects on the dependent variable by decision making:

- If F count $<$ F table, then Ho is accepted. This means that there is no significant effect between the independent variables together on the dependent variable at the $5 \%$ significance level.

- If the value of $\mathrm{F}$ count $\geq \mathrm{F}$ table, then Ho is rejected. This means that all regression coefficients are simultaneously significant at the $5 \%$ significance level.

Test of the Coefficient of Determination (R Square)

The coefficient of determination test shows the ability of the independent variables in causing the dependent variable to exist. The value of the coefficient of determination is in the range 0 and 1 . A value of 2 which is close to 0 means that the ability of the independent variable to explain the dependent variable is very limited (Ghozali, 2012).

Table 5. Regression Test Results of X1 and X2 on $\mathrm{Y}$ 


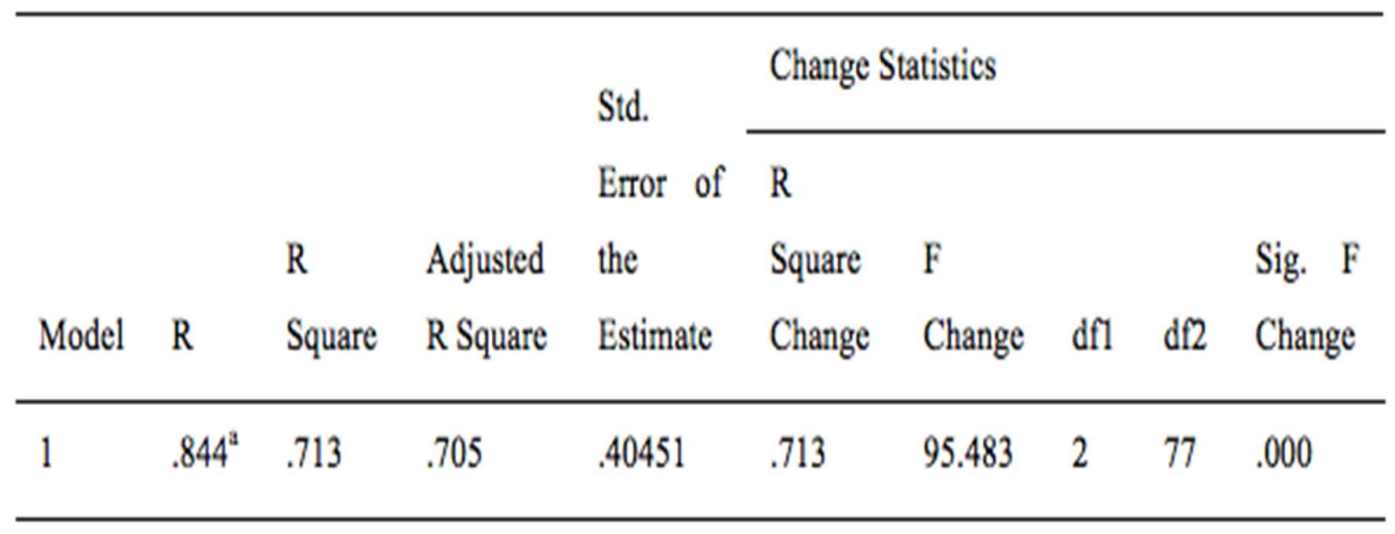

a. Predictors: (Constant), X2, X1

b. Dependent Variable: $Y$

Coefficients ${ }^{\mathrm{a}}$

$\begin{array}{lll}\text { Unstandardized } & \text { Standardized } & \text { Collinearity } \\ \text { Coefficients } & \text { Coefficients } & \text { Statistics }\end{array}$

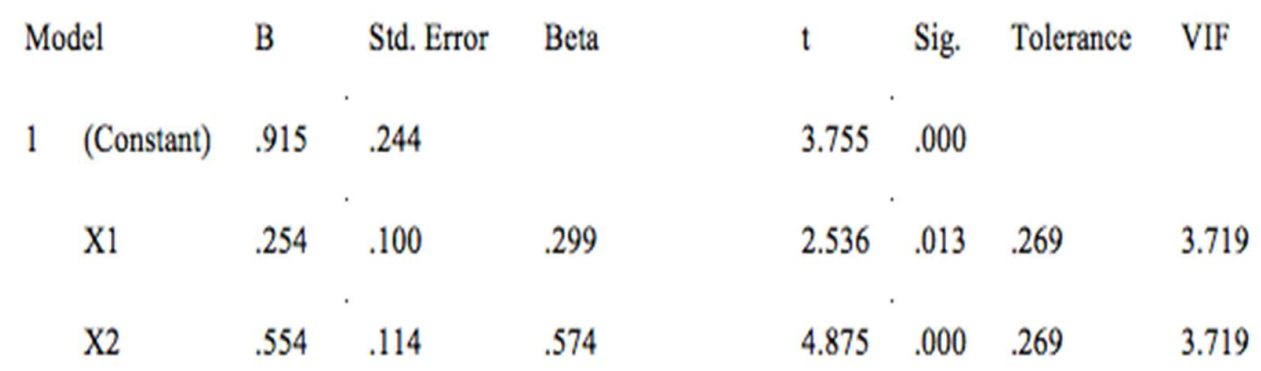

a. Dependent Variable: $Y$

\section{Result and Discussion}

\section{Overview of Research Participants}

Based on the gender category, the number of male participants was 37 (46.3\%) and female participants were $43(53.8 \%)$. The categories of participants based on age are divided into five age groups. From the data obtained, it can be seen that participants aged 17-22 years amounted to 21 people $(26.3 \%)$, ages $23-28$ years amounted to 46 people $(57.5 \%)$, ages $29-34$ years amounted to 5 people $(6,3 \%), 2$ people 
aged $35-40$ years $(2.5 \%)$, and 6 people aged 41 and over $(7.5 \%)$. Then, the participant's work is divided into five categories including students or college students with a total of 2 people (2.5\%), 18 private employees (22.5\%), 41 self-employed people $(51.2 \%), 11$ civil servants $(13,8 \%)$, and other occupations amounted to 8 people $(10.0 \%)$.

In addition, participant income data is also divided into five categories. Participants with an income below IDR 2,500,000, - per month amounted to 8 people $(10.0 \%)$, income of IDR 2,500,001, - up to IDR 5,000,000, - totaling 27 people $(33.8 \%)$, income of IDR 5,000,001, - to IDR 10,000,000, - totaling 28 people (35\%), and participants with an income of IDR 10,000,001, - and over 17 people (21.3\%). Of the 80 participants, 58 (72.5\%) have used PT XYZ and 22 (27.5\%) have never used PT XYZ. In one year, 27 people (33.8\%) use PT XYZ 1-2 times, 15 people (18.8\%) use PT XYZ 3-5 times, 16 people (20.0) use tickets. com more than 5 times, and 22 people $(27.5 \%)$ have never used PT XYZ in a year.

\section{Variable Regression Test of PU and PEU on BI}

Furthermore, the researcher conducted a regression test on the Perceived Usefulness (PU) and Perceived Ease of Use (PEU) variables on Behavioural Intention (BI). The regression test aims to determine the effect of the independent variable on the dependent variable, both individually and collectively. The significance of $p>0.05$ indicates no influence of the independent variables on the dependent variable, and etc.

The PU and PEU regression test results simultaneously on BI have a value of $\mathrm{F}$ $=95,483$ with $\mathrm{r}=0.844, \mathrm{p}=0.000<0.05$. This means that PU and PEU have a positive and significant relationship with BI. It is known that the value of R Square (R2) is 0.713 or it means that the influence of PU and PEU is $71.3 \%$ on $\mathrm{BI}$, while the rest is influenced by other factors. The research hypothesis is accepted because there is a significant effect of PU and PEU on BI in using PT XYZ. The higher the benefits and convenience felt by customers towards PT XYZ, the higher the customer's intention to use PT XYZ.

The regression test results based on PU on BI show $F=129,420, t=11,376, p=$ $0.000<0.05$ This means that PU has a positive influence on BI. It is known that R Square (R2) is 0.624 or it means that the influence of PU on BI is $62.4 \%$. Then, the regression test results PEU shows the value of $F=172,519, t=13,135, p=0.000<0.05$. This means that PEU has a positive influence on BI. It is known that R Square (R2) is 0.689 or it means that PEU has a contribution of $68.9 \%$ to BI. Thus, it can be concluded that the PEU variable has a higher effect on customer BI in using PT XYZ than the PU variable.

Table 6. Regression Test Results of X1 to $\mathrm{Y}$ 


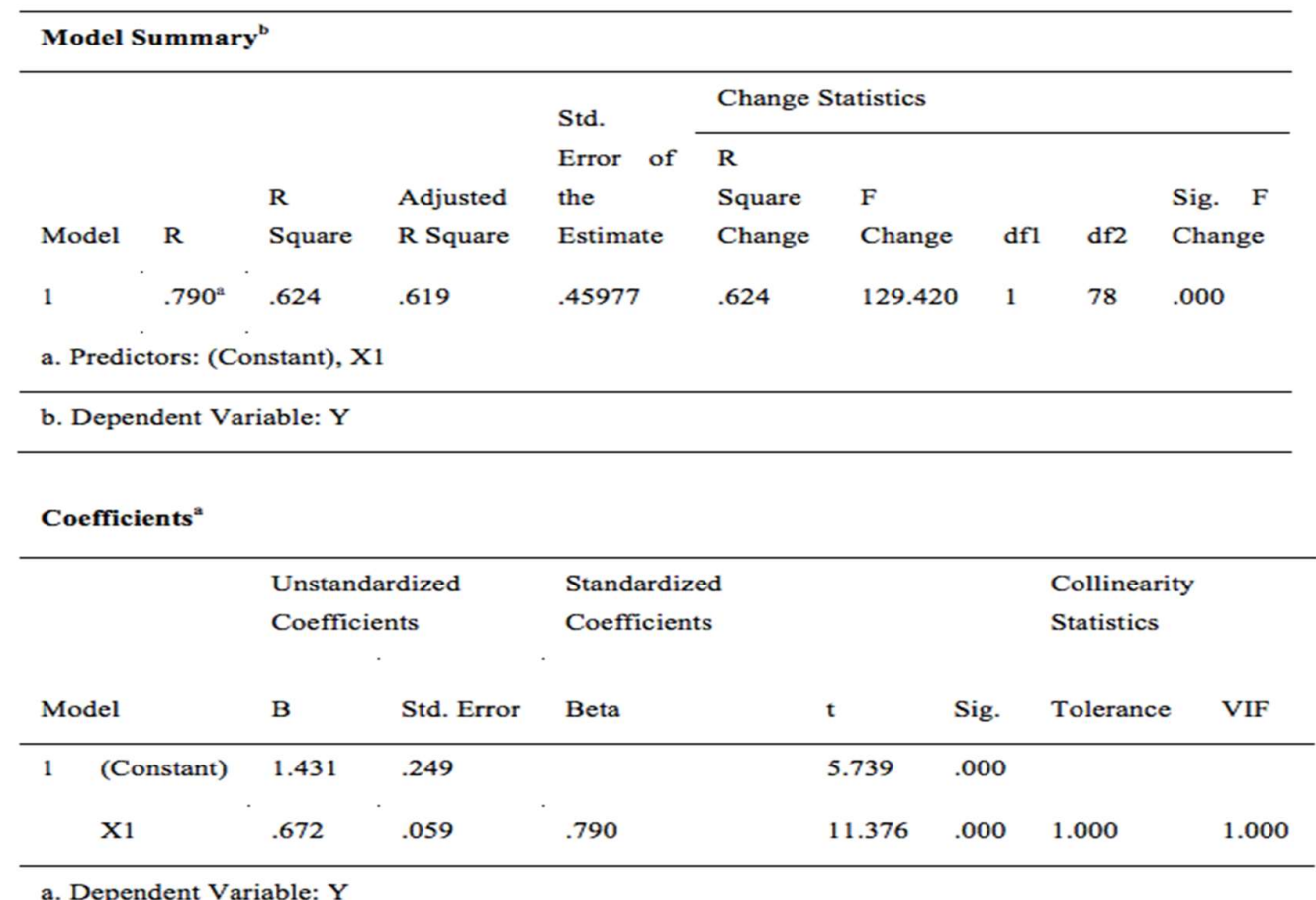

Table 7. Regression Test Results of X2 to $\mathrm{Y}$

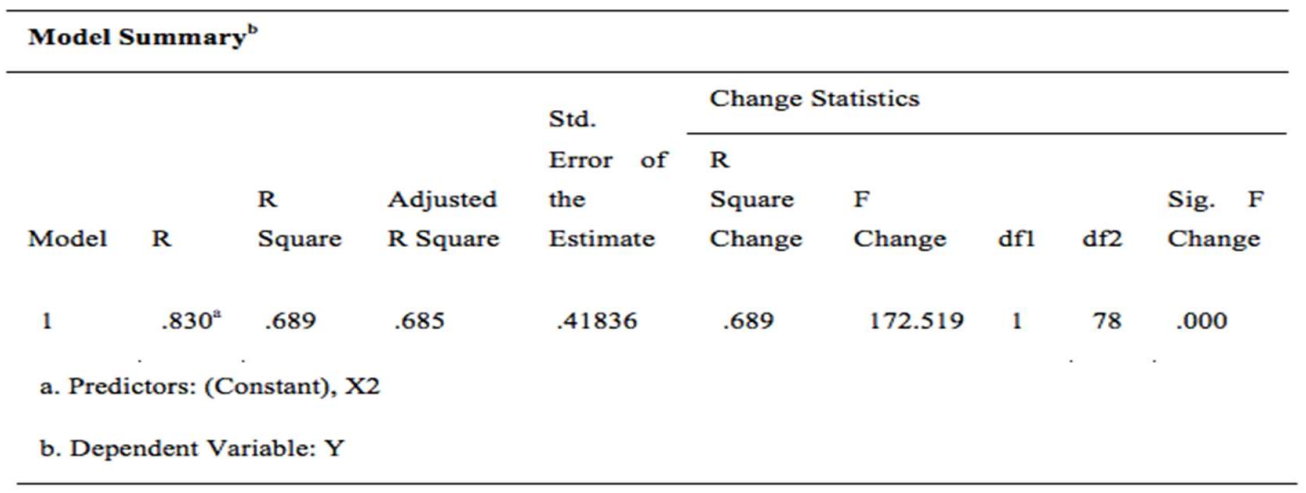

\begin{tabular}{|c|c|c|c|c|c|c|c|c|}
\hline \multicolumn{9}{|c|}{ Coefficients ${ }^{a}$} \\
\hline & & \multirow{2}{*}{\multicolumn{2}{|c|}{$\begin{array}{l}\text { Unstandardized } \\
\text { Coefficients }\end{array}$}} & \multirow{3}{*}{$\begin{array}{l}\text { Standardized } \\
\text { Coefficients }\end{array}$} & \multirow[b]{3}{*}{$\mathrm{t}$} & \multirow[b]{3}{*}{ Sig. } & \multirow{2}{*}{\multicolumn{2}{|c|}{$\begin{array}{l}\text { Collinearity } \\
\text { Statistics }\end{array}$}} \\
\hline & & & & & & & & \\
\hline \multicolumn{2}{|c|}{ Model } & B & Std. Error & & & & Tolerance & VIF \\
\hline \multirow[t]{2}{*}{1} & (Constant) & .967 & .251 & & 3.854 & .000 & & \\
\hline & $\mathrm{X} 2$ & .800 & .061 & .830 & 13.135 & .000 & 1.000 & 1.000 \\
\hline
\end{tabular}

a. Dependent Variable: Y

\section{Discussion}


The Effect of Perceived Useful on Behavioural Intention

Based on the results of the t-test, the PU value got a smaller score of 1.536 compared to the error rate of $5 \%(<0.05)$. It can be concluded that the PU variable in this study has an effect on BI for PT XYZ users. The results of this study are supported by the statement of Renadie \& Sharif. (2019) who say that PU affects BI.

According to Lockett et al. and $\mathrm{Hu}$ et al. in $\mathrm{Hu}$ et al. (2019); Renadie and Sharif (2019) PU consists of several factors, namely such as making it easier, useful, saving time, being able to meet needs, and increasing efficiency The results of this study are consistent with the statement of Davis (1989) in Lu et al. (2003) which states that PU refers to user awareness of the effectiveness, productivity, performance, and benefits of using technology. If users think a technology has been useful, more and more people will use the technology and want to use the technology more. Referring to the theory above, it can be seen that the PT. XYZ application can answer and fulfill the factors of PU. In the future PT. XYZ must continue to be able to maintain service in order to maintain customer satisfaction.

The Effect of Perceived Ease of Use on Behavioural Intention

The PEU $t$ statistical result got a score of 4,875 where this result met the standard as an acceptable variable $(<0.05)$. PEU has a significant effect on BI in the application context PT XYZ. Several sources said that several factors of PEU include, easy to understand, simple in use, minimal interference, and easy access according to Cheng et al. and Wang et al. in Hu et al. (2019); Renadie and Sharif (2019). The results of this study are consistent with the statement of Venkatesh \& Moris (2000) which states that PEU has an effect on BI. It should be noted that as a service provider, PT XYZ also needs to pay attention to the convenience of its customers.

\section{Conclusion and Recommendation}

\section{Conclusion}

Based on the results of the research and analysis described in data analysis and discussion, this study finds the conclusion that:

1. The partial test results obtained from the $t$ test show that Perceived Usefulness (PU) and Perceived Ease to Use (PEU) have a significant effect on customer Behavioural Intention (BI) in using PT XYZ.

2. Through the regression test results, it can be concluded that the effect of PEU is greater than PU on BI in the use of PT XYZ.

\section{Recommendation}


Based on the regression test results which prove that PEU has more influence on BI than PU, PT XYZ should focus more on simplifying the system for using the PT XYZ application and website. Through the descriptive analysis provided, most users are individuals of productive age. This can be caused by older users who do not understand the use of the technology offered. PT XYZ can increase knowledge or provide an easier service to help users who don't understand. For example, PT XYZ can hold an annual exhibition to increase their brand awareness as well as provide transaction opportunities for new users who do not understand how to transact online. Apart from that, PT XYZ can also offer a complete travel package which includes lodging, airplane tickets, tourist attractions, tour guides, transportation at destinations, and more. The package can also be modified according to the customer's wishes and budget. In this way, PT XYZ can increase PEU and PU because some individuals prefer to travel on tours rather than planning their own trips.

With the increasing development of cyber-crime, PT XYZ must also be aware of these threats that can attack the organizational system at any time and can cause losses. Regular security system updates can prevent cyber-attacks and reduce the down time of PT XYZ 's application or website. This can have an influence on the trust and intention of customers to use it. Thus, it can be said that trust is another factor that can influence BI.

PT XYZ can work with an outsourcing company that has expertise in handling the information systems and transaction routes used. By using trusted outsourcing services, PT XYZ can focus their capacity and capabilities to improve customer service, achieve goals and produce a more efficient work structure while ensuring that their systems are protected. This is done to maintain user trust and convince potential new users.

\section{References}

Turban, E., Outland, J., King, D., Lee, J, K., Liang, T, P., \& Turban, D, C. (2018). Electronic Commerce 2018, a managerial and social networks perspective, (9th ed.). Switzerland: Springer International Publishing AG. DOI: 10.1007/978-3-3190587158.

Weerasinghe, S., \& Hindagolla, M, C, B. (2018). Technology acceptance model and social network sites (SNS): a selected review of literature, Global Knowledge, Memory and Communication, http:/ / doi.org/10.1108/GKMC-09-2017-0079.

Aditya, R., \& Wardhana, A. (2016). Pengaruh perceived usefulness dan perceived ease of use, Jurnal Siasat Bisnis , 24-32. 
Hussein, L. A., Baharudin, A. S., Jayaraman, K., \& Kiumarsi, S. (2019). B2B E-commerce Technology Factors With Mediating Effect Perceived Usefulness In Joranian Manufacturis SMES, Journal of Engineering Science and Technology, 411-429.

Lee, N., Lee, S., \& Lee, H. (2015). The Effect of Experience Quality on Perceived Value, Satisfaction, Image and Behavioural Intention of Water Park Patrons: New versus Repeat Visitors, International Journal of Tourism Research, Int. J. Tourism Res, 82-95.

Osman, Z., Alwi, N. H., \& Khan, B. N. (2015). A study of mediating effect of attitude on perceived ease of use and students intention to use online learning platform among online learning institutions in Malaysia. 30-50.

Susanto, T. D., \& Aljoza, M. (2015). Individual Acceptance of e-Government Services in a Developing Country: Dimensions of Perceived Usefulness and Perceived Ease of Use and the Importance of Trust and Social Influence, Elsevier, 622-629.

Maryuliana., Subroto, I, M, I., \& Haviana, S, F, C. (2016). Sistem Informasi Angket Pengukuran Skala Kebutuhan Materi Pembelajaran Tambahan Sebagai Pendukung Pengambilan Keputusan Di Sekolah Menengah Atas Menggunakan Skala Likert, Jurnal Transistor Elektro dan Informatika (TRANSISTOR EI), 1(2), 1-12.

Ghozali, I.2012. Aplikasi Analisis Multivariate Dengan Program SPSS. Semarang. Badan Penerbit: Universitas Diponegoro.

Sugiyono. 2015. Metode Penelitian Pendidikan, PendekataN Kuantitatif, Kualitatif dan R\&D. Bandung: Alfabeta.

Bungin, M. B. (2013). Metodologi Penelitian Sosial dan Ekonomi. Jakarta: Kencana.

Venkatesh, V., dan Michael G. Moris, (2000), “Why Don't Men Ever Stop to Ask for Directions? Gender, Social Influence, and Their Role in Technology Acceptance and Usage Behaviour", MIS Quarterly, 24/1.

Muslim, A. (2019). 2019, Pengguna Internet Tembus 175 Juta. Retrieved from https:/ / id.beritasatu.com/home/2019-pengguna-internet-tembus-175juta/184148

Ramadhan, B. (2018). Inilah Perkembangan Digital Indonesia Tahun 2018. Retrieved from https:/ / www.goodnewsfromindonesia.id/2018/02/06/inilah-perkembangan digital-indonesia-tahun-2018

Handajani, P. R., \& Wicaksana P. S. (2018). User's Personal Room in the Internet Room of the University of Indonesia Library. Retrieved from http://arsitektur.studentjournal.ub.ac.id/index.php/jma/article/view/716 
Wikipedia. Tiket.com. Retrieved from https://id.wikipedia.org/wiki/Tiket.com COMMONS. File: Logo-ticket-com.png. Retrieved https://commons.wikimedia.org/wiki/File:Logo-tiket-com.png

Fishbein, M., and I. Ajzen. 1975. Believe Attitude, Intention and Behavior: An Introduction to Theory and Research. Reading, Massachusetts: Addison-Wesley Publishing Company.

Igbaria M, Zinatelli.1997. Personal Computing Acceptance Factors in Small Firm: A Structural Equation Modelling. Management Information System Quarterly, 21(3)

Investorid. (n.d.). 2019, Pengguna Internet Tembus 175 Juta. Retrieved October 24, 2020, from https:/ /investor.id/archive/ 2019-pengguna-internet-tembus-175juta

Setiawan, W. (2017). Era Digital dan Tantangannya [PDF]. Bandung: Seminar Nasional Pendidikan.

Lu, June., Chun-Seng Yu, Chang Liu, James .E. Yao. (2003). 'Technology acceptance model for wire-less internet.' Internet Research, 13(3): 206-222.

Davis, Fred D. (1989). 'Perceived usefulness, perceived ease of use, and user acceptance of informa-tion technology.' MIS Quarterly, 13(3): 319-340.

Jamaludin, F. (2015). Begini Potensi Pasar Online Travel di Indonesia. Retrieved from https:// www.merdeka.com/teknologi/beginipotensi-pasar-online-travel-di-indonesia.html 